\title{
Circulation of Selenium in the Environment
}

*

Institute;

**

Department of Cereal Crop Production, Institute of Soil Science and Plant Cultivation - State Research

Department of Soil Science Erosion and Land Conservation, Institute of Soil Science and Plant

Cultivation - State Research Institute, ORCIDE: 0000-0003-0148-2999

e-mail: mrozewicz@iung.pulawy.pl

Keywords:

selenium, toxicity, deficiency, soil, plant, food enrichment

\section{Abstract}

In order to function properly, every living organism must have favourable conditions for its operation, i.e. it must be systematically supplied with the necessary nutrients. On the example of selenium (Se), it can be seen how important is the right balance between providing the right amount of it, without exceeding the level above which it is toxic. The amount of Se in soil is closely correlated with its content in the parent rock; therefore, it differs depending on the soil type and may change even in a small area. Considerable dispersion of the element in the soils of Poland is related to their formation, mainly from dump materials of various glaciations. The problem of maintaining the balance between deficiency and excess of Se in the diet of humans and animals is related primarily to the uneven distribution of this element in nature. In this paper, on the basis of scientific literature, the current issues related to the deficiency and excess of Se in the soil and its possible sources are presented. The relationship between the content in the soil and the supply of Se in plants, animals and humans was also shown. The aim of this study was to summarise the state of knowledge on the complexity of Se occurrence in the environment and its importance in the soil-plant-animals-human system.

(c) IOŚ-PIB

\section{INTRODUCTION}

Selenium (Se, Latin: selenium) as an element was discovered in 1817, by the Swedish chemist Jan J. Berzelius, who was studying the residue from chalcopyrite (CuFeS2), used to produce sulphuric acid [Duntas and Benvenga 2015]. The first information regarding this toxicity of excess Se was found in the thirteenth century. Marco Polo, during a trip to China, noticed that horses suffered from hoof drop after eating the plants there. Much later, it was discovered that this was due to the consumption of plants with high Se content [Reid et al. 2004; Ulewicz-Magulska 2008]. Se was for a long time considered as a toxic element. This opinion was based on poisonings found in domestic animals consuming feed with high Se content [Hartikainen et al. 2000; Puzanowska-Tarasiewicz et al. 2009].

For another nearly 100 years, it was considered a toxic element. Its harmful effects were found in domestic animals consuming feed high in Se. It was not until the 1950 s that it was discovered that Se is, in certain amounts, an essential component of animal and human food, as its deficiency also causes negative consequences [Liu et al. 2018, Natasha et al. 2018]. It is an essential element for the proper functioning of animal organisms, and its deficiency in feed can cause a decrease in animal productivity and lead to many diseases, such as liver and heart degeneration [McDowell et al. 2002; ChalabisMazurek et al. 2008]. Later, its positive effects on the human body were also established when it was shown that Se deficiency in the human diet can cause oxidative stressrelated conditions, reduced fertility and increased cancer risk [Rayman 2000, 2002; Whanger 2004]. Every living organism, in order to function properly, during its life, must have created conditions conducive to its functioning, that is, a systematic supply of essential nutrients. Using Se as an example, it can be noted how important it is to have a proper balance between providing an adequate amount of it without exceeding the level above which it has a toxic effect [Natasha et al. 2018; Wang et al. 2018]. The problem of maintaining a balance between deficiency and an excess of Se in the diet of humans and animals is related to the uneven distribution of this element in nature. There are regions where an increased content of it is observed, up to values considered toxic, but also areas with a significant Se deficit in soils. Its content in soils is, therefore, being studied 
by many scientists around the world [Kushwaha et al. 2021]. They find geographical regions where very high Se deficiency is recorded in soils below the value of less than $0.01 \mathrm{mg} / \mathrm{kg}$ soil [Fordyce 2007]. Symptoms of deficiency in animals and humans are observed there. Other studies show that there are regions with high Se content, which can be considered a toxic concentration at $2018 \mathrm{mg} / \mathrm{kg}$ [Zhu et al. 2008]. In nature, all living organisms must take in food, which should provide the necessary ingredients to carry out the many vital processes of metabolism at the level of the small individual cell. Each cell of an organism constantly carries out many chemical transformations; some of their products, such as gland cells, produce hormones that affect other organs. For these processes to run smoothly and without interference, the basis is the maintenance of homeostasis. Homeostasis (Gr. homoíos - similar, equal; stásis - standing, abiding, attitude) is the ability to maintain constancy of parameters. This concept usually refers to the self-regulation of biological processes at the cellular level, but also to the whole organism. In order to maintain homeostasis, it is also necessary to balance the supply of nutrients to the body with their excretion or consumption. Each of the compounds performs specific functions in the body, and their deficiency causes disruption of the delicate homeostasis. Se, despite the fact that it is needed in smaller doses than macronutrients, still performs important functions in animal organisms. It is primarily a strong antioxidant, and in the body, it plays the role of protection of lipids against oxidation, as well as taking part in detoxification processes of the body. It is a component of selenoproteins involved in various physiological processes. The first link through which Se enters the food chain is plants. In order for them to build Se into their bodies, an adequate amount of Se is required in the soil in which they grow [Natasha et al. 2018; LópezBellido et al. 2019; Castro et al. 2020; Ngigi et al. 2020]. Subsequently, parts of plants that are used for feed or food purposes are a source of this element. At the same time, some of the animal products that come from animals fed on plant feed with higher Se content also contain more of this element and are a good source of it in the human diet.

\section{SELENIUM CONCENTRATION IN THE SOIL}

Soil is a basic reservoir for plants of important elements, which they need for their life processes. Their content and availability in the soilnotonlyaffect the properdevelopment of plants and their yield, but they also translate into the content of elements in those parts of plants that are food for humans and animals. This is especially true for Se, whose low content in soil translates into insufficient content of this element in products of plant origin. The distribution of Se in surface soils and its bioavailable forms for plants is the subject of research by many scientists. The content of Se in soil depends on many factors, which include the parent rock, the physical and chemical properties of soil (including $\mathrm{pH}$ ), organic matter, and, topography [Ngigi et al., 2020]. Typically, regions with excess Se (Se $\geq 3.0$ mg/kg) are underlain by Se-rich black shale rocks, such as Ziyang, Shaanxi Province, Enshi, Hubei Province, Taoyuan, Hunan Province, Kaiyang and Guizhou Province [Zhu et al. 2008]. However, Se-poor regions (Se $<0.175 \mathrm{mg} / \mathrm{kg}$ ) are exposed in sandstone and siltstone with low Se content, such as Suining, Sichuan Province Liangping and Chongqing City [Liu et al. 2018]. With the process of soil formation, the influence of soil physicochemical properties on Se content tends to increase [Matos et al. 2017]. Therefore, those regions without black shale also have moderate soil Se enrichment, such as Guilin and Guangxi Province [Shao et al. 2018]. It is indicated that parent materials play a key role in excessive soil Se concentration, while they have little effect on Se-rich soil. The distribution of soil Se content globally varies $\left(0.01-2 \mathrm{mg} \cdot \mathrm{kg}^{-1}\right)$, and depending on the continent and region of the world, the average content is $0.4 \mathrm{mg} \cdot \mathrm{kg}^{-1}$ [Fordyce 2005]. Regions with significantly increased Se content in soil are noted, as well as areas with Se deficiency. Very low Se content in soil (concentration below $0.05 \mathrm{mg} \cdot \mathrm{kg}^{-1}$ ) occurs in China, Finland and New Zealand [Chen et al. 2002]. Se-rich soils (above $5 \mathrm{mg} \cdot \mathrm{kg}^{-1}$ ) are located in Canada, Ireland and the western part of USA [Navarro-Alarcon and Cabrera-Vique 2008].

The studies carried out so far on the content of Se in the Polish soils indicated a large variation in the abundance of this element. The range of Se content in soils varies from deficient to excessive (highly toxic). It is determined by many factors, including the parent rock of a given soil, the intensity of processes of Se leaching and translocation from rock formations to water reservoirs, and the processes of sorption of this element by iron oxides and clay substance of the soil [Piotrowska 1984; Eich-Greatorex et al. 2007]. Therefore, the content of Se in different soil types varies. In soils formed from sands, the Se content is very low due to its leaching, whereas soils rich in organic matter and humus retain much more of this element and, thus, are more abundant in it [Borowska et al. 1994]. Bedrock is an important source of Se. Depending on its type and original Se content, it becomes a source of this element in the resulting soil due to physical and chemical weathering. Magmatic rocks contain $0.35 \mathrm{mg} \cdot \mathrm{kg}^{-1}$ of Se, whereas its much higher content is found in sedimentary rocks [Shahid et al. 2018]. Soil Se content is closely correlated with the content in the parent rock, but it can show variation even over a small area [Hao et al. 2020]. According to a study by Borowska et al. [2008] in organic and mineral-organic soils, the total Se content is $0.143-0.846 \mathrm{mg} \mathrm{kg}^{-1}$ (averagely $\left.0.497 \mathrm{mg} \cdot \mathrm{kg}^{-1}\right)$, whereas in alluvial soils, the content of total Se was $0.202-0.424 \mathrm{mg} \cdot \mathrm{kg}^{-1}$ (averagely $0.309 \mathrm{mg} \mathrm{kg}^{-1}$ ). The optimum range for Se content in soil is assumed to be 3-10 $\mathrm{mg} \cdot \mathrm{kg}^{-1}$ [Kabata-Pendias and Pendias 1999]. Skoczyliński and Patorczyk-Pytlik [2006] found that $90 \%$ of grasslands on different soil types were characterised by low Se abundance, while soil agronomic category differentiated the content of this element. Researchers found over 2.5 times higher Se content in silt soils compared to sandy soils. Darecki et al. [2015] report that the highest Selevels in soils in Poland $\left(2,3-4,2 \mathrm{mg} \cdot \mathrm{kg}^{-1}\right)$ occur in the Zachodniopomorskie, 


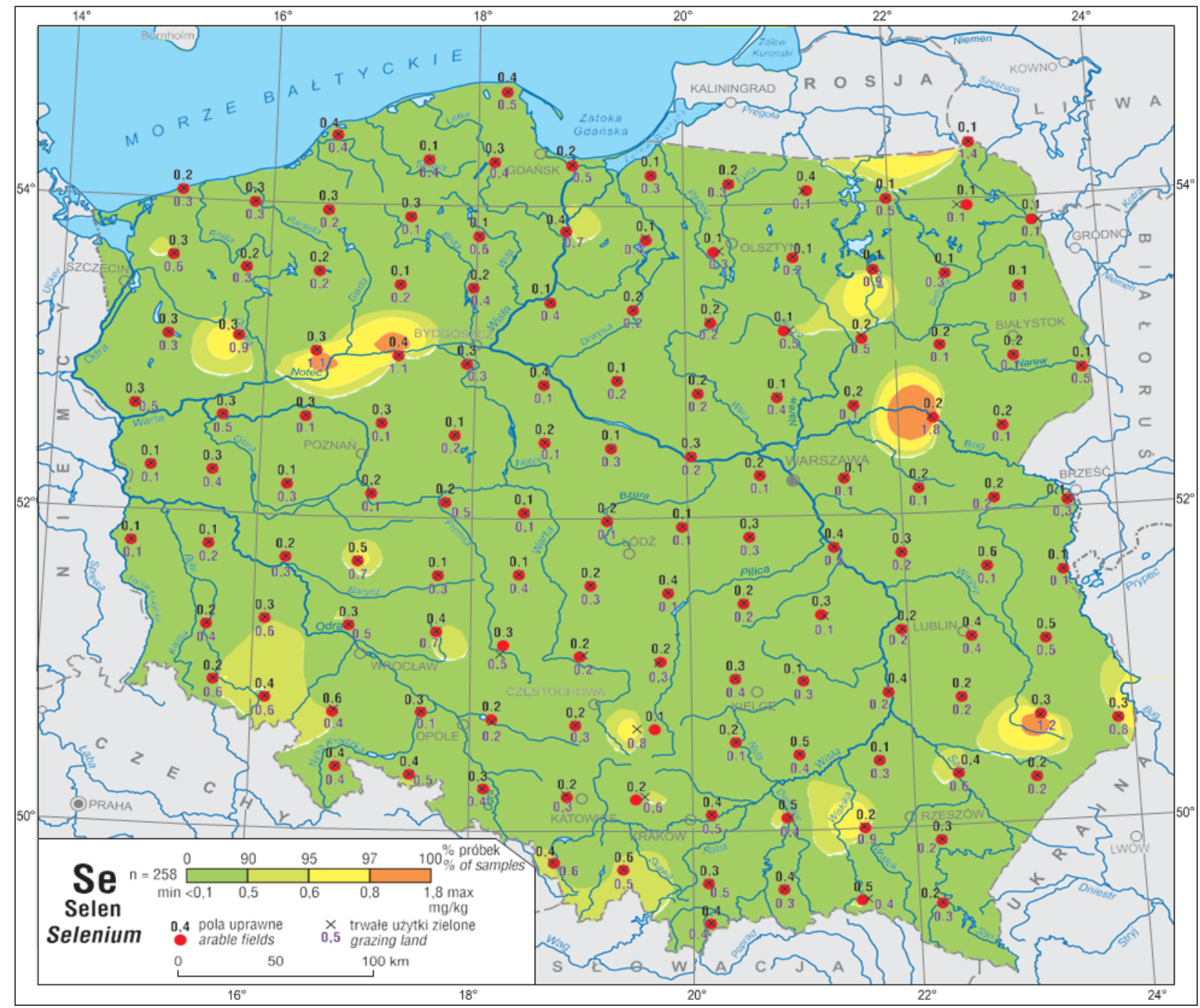

Figure 1. Selenium content in soils across Poland (0.0-0.3 m)[Pasieczna 2018]

Świętokrzyskie and Śląskie voivodships, while the lowest (0.06-0.4 $\left.\mathrm{mg} \cdot \mathrm{kg}^{-1}\right)$ are in Kujawsko-Pomorskie, Lubelskie, Dolnośląskie, Warmińsko-Mazurskie and Podlaskie. Also, analyses conducted by the National Geological Institute confirm that the amount of Se in soil varies from region to region (Figure 1).

In addition to natural sources of $\mathrm{Se}$ in soil, it can be introduced into the soil through anthropogenic sources. The most significant is the combustion of hard coal, whose mined deposits are rich in Se. Highly industrialised areas where there is significant coal consumption in the combustion process are characterised by significant Se content. Brandt et al. [2017], who studied an area with power plants extracting energy from coal combustion, found there were high levels of Se that exceeded acceptable standards. The researchers confirmed that the source of this element was coal deposits. Other authors also confirmed that a side effect of coal combustion is the emission of Se into the atmosphere, the content of which in the burned raw material was $300 \mathrm{mg} \cdot \mathrm{kg}^{-1}$ [Shahid et al.
2018]. Soil fertilisation is used in countries where soils with low Se content in the soil are found over a large area, in the absence of Se emissions from anthropogenic sources. One example of this is an area in northeastern China where Se deficiency diseases (Keshan disease and Kashin-Beck disease) have been diagnosed. The introduction of Se into the soil through fertilisation has significantly reduced the incidence of Se deficiency in humans. According to a recent study, analyses of soil samples from these areas showed that formerly applied Se fertilisation influenced soil enrichment, and currently $62.6 \%$ of the study area in the southern Songnen plain has sufficient Se supply [Yang et al. 2021]. Effective Se fertilisation of soil should include the aspect of its possibly highly bioavailable forms, while preventing leaching into deeper layers of the soil profile and its movement to groundwater. This is extremely important because of the potential toxic effects of high concentrations of Se on aquatic organisms. This was found in the studies conducted in the United States, where toxic effects of high concentrations of Se were observed in 
Table 1. Selenium forms depending on soil pH [Kabata-Pendias and Pendias 1999]

\begin{tabular}{|c|c|c|c|}
\hline $\begin{array}{c}\text { redoX } \\
\text { CONDITIONS }\end{array}$ & pH & \multicolumn{2}{|c|}{ MAIN FORMS OF SELENIUM } \\
\hline HIGHLY OXIDATIVE & $\begin{array}{c}7 \\
<2\end{array}$ & $\begin{array}{c}\mathrm{SeO}_{4}^{2-} \\
\mathrm{HSeO}_{4}^{-}, \mathrm{H}_{2} \mathrm{SeO}_{3}^{-}\end{array}$ & selenates \\
\hline transitory & $\begin{array}{l}>7 \\
<7,3\end{array}$ & $\begin{array}{l}\mathrm{SeO}_{3}^{2-} \\
\mathrm{HSeO}_{3}\end{array}$ & selenins \\
\hline highly reductive & $\begin{array}{l}>3,8 \\
<3,8\end{array}$ & $\begin{array}{l}\mathrm{HSe}^{-} \\
\mathrm{H}_{2} \mathrm{Se}^{0}\end{array}$ & selenides \\
\hline
\end{tabular}

the waters of lakes that were located near a coal-burning power plant [Brandt et al. 2017].

Organic fertilisers are also an important natural source of Se. The significant role of manure, liquid manure and slurry should be emphasised here. The change in the concept of animal nutrition concerning the introduction of premixes containing sets of microelements to feed rations makes it one of the exogenous sources of these elements introduced to soil. Higher doses of micronutrients and lack of their complete absorption in the digestive tract of animals make their excrements an important source. The use of organic manures of animal origin should now be considered a very important source of certain elements. A long-term study by Borowska and Koper [2001] showed that the application of cattle manure and pig manure increased the Se content in soil. A higher Se requirement of ruminant animals and a commonly used higher dose of this element in the ration also results in a higher Se content in excreta. This is confirmed by Borowska and Koper [2004] who found that in soil fertilised with cattle slurry, the total Se content was higher $\left(0.076-0.109 \mathrm{mg} \cdot \mathrm{kg}^{-1}\right)$ compared to its content in soil samples fertilised with swine manure $\left(0.038-0.071 \mathrm{mg} \cdot \mathrm{kg}^{-1}\right)$. The application of pig manure results in a significant increase in the total Se content of the soil while introducing a certain amount of nitrogen, which is a great advantage compared to fields fertilised with nitrogen in mineral form [Borowska et al. 2014]. It is also possible to supply Se to the soil in the form of mineral fertilisers. Se is then supplied in the anionic form: $\mathrm{SeO}_{3}{ }^{2-}$ lub $\mathrm{SeO}_{4}{ }^{2-}$ [lzydorczyk et al. 2020]. The availability of these forms of Se to plants depends on reactions occurring in soil and transformations of Se compounds and ions. The transformations of Se compounds and ionic forms are conditioned by soil properties, and soil $\mathrm{pH}$ plays a significant role. A scientific study by Patorczyk-Pytlik et al. [2015] showed that compared to soil fertilised with Secontaining mineral fertilisers, the application of manure significantly increased the Se content in white mustard seeds and straw. This indicates a higher efficiency of Se utilisation from organic fertilisers. This may be due not only to the provision of higher amounts of Se, but also to the beneficial effect on soil properties and its microbial activity, which contributes to the occurrence of Se forms better assimilated by plants. The application of mineral fertilisation of soils with Se and the simultaneous application of the addition of positive microorganisms also affects the higher availability of Se by plants [PatorczykPytlik et al. 2015]. Acidic soils contain Se in the form of Se sulfides and selenides, which are difficult for plants to access. On the other hand, in soils with neutral pH, Se occurs in the form of selenates, which are forms that are hardly available to plants. The most beneficial form of Se, which is characterised by high bioavailability, are selenates, which occur in soils with alkaline $\mathrm{pH}$ [Kabata-Pendias and Pendias 1999]. The application of organic soil fertilisation in the form of manure, by stimulating the development of soil microorganisms, increases the forms of Se available to plants. As shown in the study by Borowska et al. [2012], the content of selenate (IV) increased on average by $85 \%$ and selenate $(\mathrm{VI})$ by $37-50 \%$, depending on the method of manure storage. Due to the possibility of Se transformation into compounds that are hardly available for plants, it is more beneficial to apply foliar fertilisation with this compound [lzydorczyk et al. 2020].

\section{THE IMPORTANCE OF SELENIUM FOR PLANTS}

Se is not an essential element for proper plant function. However, its availability in soil in certain amounts has a beneficial effect on plants [Lyons et al. 2009]. Some studies show that it can have a beneficial effect on plants, stimulating their growth [Hawrylak and Szymańska 2006] and increasing their tolerance to stress factors, e.g. UV radiation [Hartikainen and Xue 1999]. As evidenced by research conducted by Hawrylak [2007], Se can counteract the stress of soil salinity. By introducing Se into the soil where there was an excess of $\mathrm{NaCl}$, the author found that Se reduced the adverse effects of excess $\mathrm{NaCl}$ in cucumber. This was evidenced by parameters such as an increase in photosynthetic pigments, proline, inhibition of lipid peroxidation and consequently a greater increase in seedling dry weight. The cited author found that a higher applied dose of Se to soil had a greater effect on alleviating the effects of salt stress. As shown in the study of PatorczykPytlik et al. [2015], enrichment of soil with Se, where there were deficiencies of this element, significantly increased 
the yield of mustard seeds but affected the lower weight of straw obtained.

Se is taken up from the soil in the same way as sulphur and is metabolised similarly. With a sufficiently high supply of readily available forms of $\mathrm{Se}$, it is metabolised similarly to sulphur and incorporated instead into the structure of the so-called sulphur amino acids. The result is selenomethionine or selenocysteine. These amino acids support plants to some extent during abiotic stresses by nullifying the action of reactive oxygen species [PilonSmits and Quinn 2010]. Selenoamino acids incorporated into plant tissue structures, once consumed by humans and animals, are a highly bioavailable source of this element. Due to the efficiency of Se uptake from soil by plants, three groups of them are distinguished:

Se hyperaccumulators, i.e. those plant species that take up and metabolise Se very efficiently by accumulating it in their tissues.

Species occurring on soils with medium or low Se content, which accumulate and metabolise Se to a lesser degree than hyperaccumulators.

Plants with a low ability to take up, metabolise and accumulate Se (this includes economically important species such as: cereals, grasses, fruits and vegetables)

The uptake of Se by the root system may be limited by the greater availability of other elemental ions that will compete with it. This applies to plants, which are classified as so-called hypoaccumulators. Studies conducted on the availability of phosphorus in soil and the associated difference in Se uptake were conducted on mustard. Patorczyk-Pytlik and Zimoch [2011] showed that with increasing phosphorus fertilisation, mustard plants took up significantly less Se. The mineral forms of phosphorus effectively competed with Se ions in the uptake of this element by plants. These studies show that in soils with too much $\mathrm{Se}$, phosphorus fertilisation can be used to prevent excessive Se accumulation in plant tissues, which can prevent excessive concentrations in plant products for humans as well as in animal feed. These studies also show that in Se-deficient soils, excessive phosphorus fertilisation can further exacerbate Se deficiency in plant products. Nitrogen fertilisation also decreases Se uptake from the soil. In a study by Borowska and Jankowiak [2002], nitrogen fertilisation was found to reduce the Se content in potato tubers. As reported by Song et al [2018], at the same Se content in soil, different plant species may show different degrees of Se accumulation in their tissues and edible parts. The researchers found that soybeans had the highest Se accumulation capacity relative to maize and rice grown in the same soil with the same Se content.

An excessive amount of $\mathrm{Se}$ in soil causes toxicity, especially in plants that have a low capacity to metabolise and remove excess of this element. Excessive accumulation of Se in soil causes inhibition of root system growth, which significantly hinders the plant's ability to absorb other nutrients and water, making it more sensitive to drought. The selenate ions $\mathrm{Se}(\mathrm{VI})$ are the best available form of Se for the plant root system. After their uptake by the root system, they are transported through the wood vessels to the green parts of plants. After their transport to individual tissues, Se ions are metabolised similar to sulphur ions. In chloroplasts, $\mathrm{Se}(\mathrm{VI})$ is reduced to $\mathrm{Se}(\mathrm{IV})$ and further reduced to Se(II) with the participation of reduced glutathione (GSH). Further downstream in the methionine biosynthesis pathway, selenomythionine is converted to dimethylselenite and then converted to volatile compounds to dimethyl diselenides (DMDSe) [Skoczylas et al. 2014]. Through selenoamino acid conversion reactions, which are significantly increased when there is an excess of Se taken up by plants, excess Se is neutralised. A series of enzymatic reactions of selenomethionine leads to a volatile product in the form of dimethylselenide or dimethyldiselenide [Gupta and Gupta 2017]. These volatile compounds secreted by plants to some extent act as repellents to insects that are phytophages. Adequate supply of Se to plants (referred to as biofortification) is one potential method to protect plants from pests. Numerous studies show that Se fertilisation is effective in preventing overgrowth of pest populations by slowing the growth of pest populations or through toxic effects even their death [Vickerman et al. 2002]. This method of control of insects feeding on washed plants is interesting due to the possibility of their control through the use of natural fertilisation of the element, which, additionally to accumulating in plant tissues, would be introduced into the trophic chain, and thus its deficiency in humans and animals could be reduced. However, the disadvantage of this solution is the possibility of toxic effects of too high doses of Se on the ecosystem, and relationships in the trophic chain within agro- and ecosystems [Łukaszewicz and Politycka 2020].

\section{THE IMPORTANCE OF SELENIUM FOR ANIMALS}

Se is an element that is more important for the proper functioning of human and animal organisms. It is essential for vital processes and deficiency or excess has negative health consequences. In the main, $\mathrm{Se}$ is found in the form of selenoproteins. Currently, 25 of them have been identified in various tissues of the body. Se is part of GSH peroxidase, which plays an important antioxidant role. This is a very important enzyme, especially during significant exercise. Se is important in maintaining the normal health of the body, but both dietary Se deficiency and excess have negative effects on the body. Se deficiency in Polish soils also manifests itself in the form of reduced Se content in animals feeding in those regions of Poland where low Se content in soil is found. Tissues from game animals in Poland may also be one of the indicators of Se abundance in Polish soils and its circulation in the trophic chain. However, these must be animals whose populations are relatively numerous and cover large areas [Mirowski 2016]. Tomza-Marciniak et al. [2010] showed that there is a positive statistically significant correlation between Se 
content in the liver and kidneys of roe deer and Se content in the soil. Based on the low Se content in the organs of roe deer and in the soil, they concluded that the study area was deficient in Se. Also in livestock/breeding animals in the late 1980s, the first signs of muscular dystrophy and reproductive disorders in horses, sheep and cattle due to Se deficiency were reported in southeastern regions of Poland [Grzebuła 1989]. All animals, both free-living and farmed, are exposed to Se deficiency. However, Se deficiency may become apparent particularly in animals undergoing intense exercise. This is especially true for horses, which undergo intensive training and have a higher Se requirement. Many horses kept in Se-deficient areas are deficient in this nutrient. According to various authors, a Se deficiency in horses can be said to occur when its concentration in blood is below 55-75 $\mu \mathrm{g} / \mathrm{l}$ [Ludvíková et al. 2005]. In horses of different ages, the demand for Se is differentiated, which is manifested by a higher content of this element in the muscles of young horses [Szucik et al. 2014]. A very important group of farm animals sensitive to Se deficiency are ruminants (cattle, sheep, goats). The most commonly used criterion for assessing Se supply in these animals is the content of this element in their blood serum [Kruzhel et al. 2014]. Its deficiency in this group of animals causes serious health consequences; hence, it is important to constantly monitor the Se supply of cattle, goats and sheep.

The first element to incorporate this element is the soil, which should have the right amount and form of Se that is taken up by plants, and then they are the nutritional source of this element for humans and animals. In cattle nutrition, plant forages, due to the nature of nutrition, are the primary source of Se. The total Se intake depends on the abundance of this element in soil. Due to low Se abundance in Polish soils, premixes containing all necessary elements are added to animal feeds. They also supplement Se in animal diets, and additionally, the unabsorbed part of this element is excreted with urine and faeces. Fertilising with these organic fertilisers introduces Se into the soil. The natural way to introduce Se into animal products is mineral fertilisation with Se. Tufarelli et al. [2016] using mineral fertilisation with Se tritordeum [a cereal developed by interspecies hybridisation], obtained an increase in the Se content of the grains. The researchers then used these grains in feed for laying hens. Feeding them with these grains resulted in an increase in the Se content of eggs, and thus this product may be a source of Se in the diets of humans who consume it. Feeding organic forms of Se in laying hen feed is more effective in increasing the content of this element in eggs than inorganic forms [Boruta et al. 2007].

\section{THE IMPORTANCE OF SELENIUM IN HU MAN FOOD}

Since Se has a number of important functions in the body of not only animals, but also humans, its adequate supply is crucial for human health. Numerous scientific studies have shown that the correct dose of Se provided with the diet reduces the risk of heart disease, leukemia and other cancers in humans [Ratajczak and GietkaCzernel 2020]. This includes cancers of various organs in the lung, breast, ovary and prostate, among others. In addition, long-term dietary Se deficiency results in heart enlargement and failure, increased risk of heart and liver disease, symptoms of goiter and hypothyroidism, and alimentary muscular dystrophy. In pregnant women, it can cause irreversible fetal changes, while in men there is decreased sperm motility [Behne et al. 1996; Nicoll et al. 1999]. It also appears that many diseases of aging in humans may be due to the consequences of a deficiency of this element. The established daily intake of Se from food for humans is $55 \mu \mathrm{g}$, while a level of $400 \mu \mathrm{g}$ of Se per day is considered possibly harmful [Kałabun 2020]. Individuals who are more physically active have a higher Se requirement, which is related to a higher energy demand and an increase in oxidative processes in the body that $\mathrm{Se}$ prevents. It is also an element with great potential in the prevention and treatment of various diseases caused by Se deficiency, but also cancer [Żarczyńska et al. 2013]. The human diet consists of both plant and animal products; therefore, both of these sources can provide Se. Cereal grains consumed from plantations fertilised with Se where there is a deficiency of this element in soils could also be a direct source of this element in the human diet. Zagrodzki [2000] indicates that cereals and cereal products provide about $36 \%$ of Se intake from food. Cereal products can be enriched in Se by fertilising cereals with this element, which accumulates in grains. They can also be enriched in this element by addition of properly prepared Se yeast. One of the methods used to enrich bread with this element by Diowksz et al. [1999] was the use of yeast and cereal germ enriched with Se. The researchers thus obtained bread with $46 \%$ higher Se content than conventional bread. The problem, however, is the heat treatment of cereal products, which, depending on its duration and the type of product itself, causes Se losses. Baking bread, however, causes loss of much of the Se due to the Maillard reaction between selenomethionine and glucose. Volatile Se compounds are then formed that cause the loss of this element from the product [Sager 2006].

Products of animal origin are also a source of Se in the human diet, with eggs and meat having the largest share in the dietary supply of this element - up to $30 \%$ of the daily Se intake [Zagrodzki 2000]. Dairy products provide up to $14 \%$ of the human daily Se intake [Zagrodzki 2000]. Milk available on the Polish market generally has low Se content, which stems from the low amount of Se in the soil and its deficiency in plant feed [Brzóska et al. 2018].

\section{CONCLUSIONS}

Because of the important biological functions of Se in human and animal organisms, there is a need for scientific research on its circulation in various trophic chains. 
Soil, which is one of its most important sources, plays an important role here. According to national research, soils in Poland have insufficient content of this element, which translates into insufficient uptake by plants and, consequently, the occurrence of deficiencies in humans and animals. Its deficiency in Polish soils is likely to worsen as a result of reduced emission of Se to the environment from coal combustion and other anthropogenic sources. However, the use of natural fertilisers may contribute to supplementation of some of its deficiencies in soils. The problem is, however, the reduction of their consumption, so the possibility of introducing mineral Se fertilisation should also be considered. Fertilisation with Se is one of the methods to ensure adequate supply of this element to plants and then to people and animals. However, due to possible toxic effects, its content in soil should be continuously monitored, especially where its emission to the environment from anthropogenic sources is possible. Although $\mathrm{Se}$ is not essential for plants, its supply to soil has a beneficial effect, except when certain plant toxicity thresholds are exceeded.

\section{REFERENCES}

BEHNE D., WEILER H., KYRIAKOPOULOS A. 1996. Effects of selenium deficiency on testicular morphology and function in rats. Reproduction, 106: 291-297.

BOROWSKA K., KOPER J. 2001. Zawartość selenu ogółem w glebie po wieloletnim nawożeniu gnojowicą. Zeszyty Problemowe Postępów Nauk Rolniczych, 476: 69-74.

BORKOWSKA K., KOPER J. 2004. Zmiany zawartości selenu w glebie nawożonej gnojowicą. Roczniki Gleboznawcze, 3: 53-58.

BOROWSKA K., KOPER J., GRABOWSKA M. 2012. Wpływ wartości nawozowej obornika w zależności od jego przechowywania na zawartość selenu i jego frakcji fitoprzyswajalnych w glebie na tle aktywności katalazowej. Ochrona Środowiska i Zasobów Naturalnych, 54: 141-149.

BOROWSKA K., KOPER J., KOZIK K., RUTKOWSKA A. 2014. Effect of slurry fertilization on the selenium content and catalase activity in lessive soil. Journal of Elementology, 19[3]: 649-659.

BOROWSKA K., MALCZYK P., KĘDZIA W. 1994. Zawartość selenu w glebach uprawnych i leśnych województwa bydgoskiego. Zeszyty Naukowe. Polska Akademia Nauk. Komitet Naukowy przy Prezydium PAN Człowiek i Środowisko, 8: 33-37.

BOROWSKA K, KOPER J, DAZBKOWSKA-NASKRĘT H. 2008. Zawartość selenu w wybranych typach gleb pomorza i kujaw na tle aktywności peroksydaz. Roczniki Gleboznawcze - Soil Science Annual, 59[1]: 52-59.

BOROWSKA K., JANKOWIAK J. 2002. Wpływ nawożenia organicznego i zróżnicowanych dawek azotu na zawartość selenu w bulwach ziemniaka i glebie na tle jej niektórych właściwości. Acta Agrophysica, 70: 55-63.

BORUTA A., ŚWIERCZEWSKA E., ROSZKOWSKI T. 2007. Wpływ organicznej i nieorganicznej formy selenu na skład morfologiczny jaj i zawartość selenu w masie jajecznej. Medycyna Weterynaryjna, 63: 238-241.

BRANDT J.E., BERNHARDT E.S., DWYER G.S., DI GIULIO R. T. 2017. Selenium Ecotoxicology in Freshwater Lakes Receiving Coal Combustion Residual Effluents: A North Carolina Example. Environmental Science \& Technology, 51:2418-2426.
BRZÓSKA F., ŚLIWINSKI B., PIETRAS M. 2018. Zawartość selenu w mleku spożywczym w Polsce. Roczniki Naukowe Zootechniki, 45[1]: 89-98.

CASTRO D.A., SOUZA J.H.R., MORAES M.F., WILSON L., BROADLEY M. R., TARDIN A. B. B., LIMA R. M. B., SILVA K.E., WHITEP.J.2020. Accumulation and distribution of selenium in Brazil nut tree in relation to soil selenium availability. Selenium Research for Environment and Human Health: Perspectives, Technologies and Advancements. Proceedings of the 6 th International Conference on Selenium in the Environment and Human Health, October 27-30, 2019, Yangling, Xi'an, China, pp. 69-70.

CHAŁABIS-MAZUREK A., WAŁKUSKA G., KURSA K. 2008. Zawartość selenu $w$ organizmie owiec na tle zasobności w ten pierwiastek gleb i roślinności łąkowej makroregionu lubelskiego. $X$ Sympozjum Trace Elements in the Enviroment, 5: 57-58.

CHEN L., YANG F., XU J., HU Y., HU Q., ZHANG Y., PAN G. 2002. Determination of selenium concentration of rice in China and effect of fertilization of selenite and selenate on selenium content of rice. Journal of Agricultural and Food Chemistry, 50: 5128-5130.

DARECKI A., SAEID A., GÓRECKI H. 2015. Selen w perspektywie fortyfikacji roślin o znaczeniu gospodarczym dla Polski. Wiadomości chemiczne, 69, 11-12: 1067-1081.

DIOWKSZ A., PĘCZKOWSKA B., AMBROZIAK W., WŁODARCZYK M. 1999. Wzbogacone w selen pieczywo na zakwasach. Żywność Nauka Technologia Jakość, Suplement, 6[4]: 195-203.

DUNTAS L.H., BENVENGA S. 2015. Selenium: an element for life. Endocrine, 48: 756-775.

EICH-GREATOREX S., TRINE A S., ØGAARD A.F., AASEN I. 2007. Plant availability of inorganic and organic seleniumfertiliser as influenced by soil organic matter content and $\mathrm{pH}$. Nutrient Cycling in Agroecosystems, 79[3]:221-23. doi: 10.1007/s10705-007-9109-3

FORDYCE F. 2007. Selenium Geochemistry and Health. Ambio, 36: 94-97. https://www.jstor.org/stable/4315793 FORDYCE F.M. 2005. Selenium deficiency and toxicity in the environment: Essentials of medical geology-impacts 
of the natural environment on public health London. Elsevier, pp 373-415.

GRZEBUŁA S. 1989. Studia nad pokarmową dystrofią mięśni u źrebiąt, Rozprawa habilitacyjna. Akademia Rolnicza, Lublin, 1989.

GUPTA M., GUPTA S. 2017. An overview of selenium uptake, metabolism and toxicity in plants. Frontiers in Plant Science, 7 [2074]: 1-14.

HAO L, ZHANG J, ZHANG S., MA S., LI B., LONG J., FAN J., LUO K. 2020. Distribution characteristics and main influencing factors of selenium in surface soil of natural selenium-rich area: a case study in Langao County, China. Environmental Geochemistry and Health, 43: 333-346. https://doi.org/10.1007/s10653-020-00711-2

HARTIKAINEN H., XUE T. 1999. The promotive effect of selenium on plant growth as trigged by ultraviolet irradiation. Journal of Environmental Quality, 28: 12721275.

HARTIKAINEN H., XUE T., PIIRONEN V. 2000. Selenium as an anti-oxidant and pro-oxidant in ryegrass. Plant and Soil, 225: 193-200. doi:10.1023/A:1026512921026.

HAWRYLAK B. 2007. Fizjologiczna reakcja ogórka na stres zasolenia w obecności selenu. Roczniki Akademii Rolniczej w Poznaniu, 383[41]: 483-486.

HAWRYLAK B., SZYMAŃSKA M. 2006. Selen-pierwiastek pożądany $w$ żywieniu warzyw liściowych? Folia Horticultura, Supl. 1: 171-175.

IZYDORCZYK G., LIGAS B., MIKUŁA K. WITEK-KROWIAK A., MOUSTAKAS K., CHOJNACKA K. 2020. Biofortification of edible plants with selenium and iodine-A systematic literature review. Science of The Total Environment, 141983.

KABATA-PENDIAS A, PENDIAS H. 1999. Biogeochemia pierwiastków śladowych. Wyd. PWN, Warszawa.

KAŁABUN M. 2020. Wzbogacanie w selen roślin uprawnych. Praca doktorska, Uniwersytet Warszawski.

KRUZHEL B., BAKOWSKA M., VOVK S., NOWAKOWSKA E.,SERGEI P. 2014. Selenium in the diet of ruminants. Acta Scientiarum Polonorum. Zootechnica, 13[4]:5-16.

KUSHWAHA A., GOSWAMI L., LEE J., SONNE C., BROWN R. J., KIM K. H. 2021. Selenium in soil-microbe-plant systems: Sources, distribution, toxicity, tolerance, and detoxification. Critical Reviews in Environmental Science and Technology, 147: 1-42.

LIU Y.L., YUAN Y.Y., LUO K.L. 2018. Regional distribution of longevity population and elements in drinking water in Jiangjin District, Chongqing City. Biological Trace Element Research, 184:287-299. doi 10.1007/s12011017-1159-z

LÓPEZ-BELLIDO F.J., SANCHEZ V., RIVAS I., LÓPEZ-BELLIDO R.J., LÓPEZ-BELLIDO L. 2019. Wheat grain selenium content as affected by year and tillage system in a rainfed Mediterranean Vertisol Field Crops Research, 233[1]: 41-48. https://doi:10.1016/j.fcr.2019.01.006

LUDVÍKOVÁ E., PAVLATA L, VYSKOĂIL M P. JAHN P. 2005. Selenium Status of Horses in the Czech Republic. Acta Veterinaria Brno 74: 369-375.
LYONS GH, GENC Y, SOOLE K., STANGOULIS J. C. R., LIU F., GRAHAM R. D. 2009. Selenium increases seed production in Brassica. Plant Soil, 318:73-80

ŁUKASZEWICZ S., POLITYCKA B. 2020. Selen w roślinach i jego wpływ na żerowanie i rozwój fitofagów. Progress in Plant Protection, 60 [2]: 119-127.

MATOS R.P., LIMA V.M., WINDMÖLLER C. C., NASCENTES C. C. 2017. Correlation between the natural levels of selenium and soil physicochemical characteristics from the Jequitinhonha Valley (MG). Brazil. Journal of Geochemical Exploration, 172: 195-202.

MCDOWELL L.R., VALLE G., CRISTALDI L., DAVIS P.A., ROSENDO O., WILLINSON N.S. 2002. Selenium availability and methods of selenium supplementation for grossing ruminants. Proceedings 13th Annual Florida Ruminant Nutrition Symposium, 86-102. https://animal.ifas.ufl. edu/apps/dairymedia/rns/2002/mcdowell.pdf

MIROWSKI A. 2016. Stopień zaopatrzenia w selen wolno żyjących zwierząt z terytorium Polski. Życie Weterynaryjne, 91[03]: 166-168.

NATASHA S.M., N.K. NIAZI, S. KHALID, B. MURTAZA, I. BIBI, M.I. RASHID

NATASHA S.M., SHAHID N.M., NIAZI N.K., KHALID S., MURTAZA B., BIBI I., RASHID M.I. 2018. A critical review of selenium biogeochemical behavior in soil-plant system with an inference to human health. Environmental Pollution, 234: 915-934.

NAVARRO-ALARCON, M., CABRERA-VIQUE, C. 2008. Selenium in food and the human body: a review. Science of the Total Environment, 400(1-3): 115-141.

NGIGI P.B., DU L.G., MASINDE P.W., LACHAT C. 2020. Selenium deficiency risk in central Kenya highlands: an assessment from the soil to the body Environ. Geochem. Health, 42 [7]: 2233-2250 https://doi:10.1007/s10653019-00494-1

NICOLL A. E., NORMAN J., MACPHERSON A., ACHARYA U. 1999. Association of reduced selenium status in the aetiology of recurrent miscarriage. BJOG: An International Journal of Obstetrics \& Gynaecology, 106[11]: 1188-1191.

PASIECZNA A. 2018. Kartograficzne badania geochemiczne w Polsce. Przegląd geologiczny,66 [6]: 334-352.

PATORCZYK-PYTLIK B., CALÓW J., KARMOWSKA K. 2015. Wpływ nawożenia oraz dodatku EMFARMA ${ }^{\mathrm{TM}}$ na plon oraz pobranie selenu przez gorczycę białą. Zeszyty Naukowe Uniwersytetu Przyrodniczego we Wrocawiu: Rolnictwo, [611]: 53-63.

PATORCZYK-PYTLIK B., ZIMOCH A. 2011. The effect of soil fertilization with phosphorus on the content of selenium in white mustard plants [Sinapsis alba L.]. Nawozy i Nawożenie, 43: 67-74.

PILON-SMITS E.A., QUINN C.F. 2010. Selenium metabolism in plants. In Cell biology of metals and nutrients Springer, Berlin, Heidelberg, pp. 225-241.

PIOTROWSKA M. 1984. Zawartość selenu w uprawnych glebach Polski. Roczniki Gleboznawcze - Soil Science Annual, 35[1]: 23-31 
PUZANOWSKA-TARASIEWICZ H., KUŹMICKA L., TARASIEWICZ M. 2009. Funkcje biologiczne pierwiastków i ich związków. II. Selen, seleniany, związki selenoorganiczne. Polski Merkuriusz Lekarski, 159: 249252.

RATAJCZAK M., GIETKA-CZERNEL M. 2020. Sonoelastography in the diagnosis of thyroid focal lesions. Wiedza Medyczna, 2(2): 16-22.

RAYMAN M.P. 2000. The importance of selenium to human health. Lancet, 356: 233- 241. doi: 10.1016/S01406736[00]02490-9

RAYMAN M.P. 2002. The argument for increasing selenium intake. Proceedings of the Nutrition Society, 61: 203215 doi:10.1079/PNS2002153

REID M.E., STRATTON M.S., LILLICO A.J., FAKIH M., NATARAJAN R., CLARK L.C., MARSHALL J.R. 2004. A raport of high-dose selenium supplementation: response and toxicities. Journal of trace Elements in Medicine and Biology, 18[1]:69-74. doi: 10.1016/j.jtemb.2004.03.004

SAGERM. 2006. Selenium in agriculture, food, and nutrition. Pure and Applied Chemistry, 78: 111- 133.

SHAO Y., CAI C., ZHANG H., FU W., ZHONG X., TANG S. 2018. Controlling factors of soil selenium distribution in a watershed in Se-enriched and longevity region of South China. Environmental Science and Pollution Research, 25(20): 20048-20056.

SHAHID M., NIAZI N. K., KHALID S., MURTAZA B., BIBI I., RASHID M. I. 2018. A critical review of selenium biogeochemical behavior in soil-plant system with an inference to human health. Environmental Pollution, 234: 915-934.

SKOCZYLAS Ł., LISZKA-SKOCZYLAS M., ŻMUDZIŃSKI D., RUDNIK D. 2014. Biofortyfikacja roślin uprawnych jako metoda walki z deficytem składników mineralnych w diecie człowieka: w Składniki bioaktywne surowców i produktów roślinnych.

SKOCZYLIŃSKI M., PATORCZYK-PYTLIK B. 2006. Zawartość selenu w glebach użytków zielonych okolic Wroclawia. Fragmenta Agronomica, 23[4]: 156-164.

SONG T., SU X., HE J., LIANG Y., ZHOU T., LIU C. 2018. Selenium [Se] uptake and dynamic changes of Se content in soil-plant systems. Environmental Science and Pollution Research, 25[34]: 34343-34350.

SZUCIKK., GONDEKM., BELKOTZ., KURSA K. 2014.Zawartość selenu w mięśniach i narządach wewnętrznych koni rzeźnych w zależności od ich wieku i płci. Żywność Nauka Technologia Jakość, 5 [96]: 63-71.

TOMZA-MARCINIAK A., BAKOWSKA M., PILARCZYK B., SEMENIUK M., HENDZEL D., UDALA J., BALICKA-RAMISZ A., TYLKOWSKA A. 2010. Stężenie selenu w glebie $i$ wybranych narządach saren [Capreolus capreolus] z terenu województwa wielkopolskiego. Acta Scientiarum Polonorum. Zootechnica, 9[4]: 251-259.

TUFARELLI V, CAZZATO E, CECI E., LAUDADIO V. 2016. Selenium-fertilized Tritordeum [XTritordeum Ascherson et Graebner] as dietary selenium supplement in laying hens: Effects on egg quality. Biological Trace Element Research, 173 [1]: 219-224.
ULEWICZ-MAGULSKA B. 2008. Selen w roślinach surowych leczniczych, zawartość, rozmieszczenie i wzajemne relacje z innymi pierwiastkami [rozprawa doktorska] https://pbc.gda.pl/Content/4936/ulewicz_ magulska_062426.pdf

VICKERMAN D.B., YOUNG J.K., TRUMBLE J.T. 2002. Effect of selenium-treated alfalfa on development, survival, feeding, and oviposition preferences of Spodoptera exigua [Lepidoptera: Noctuidae]. Environmental Entomology, 31 [6]: 953-959.

Volume 392, Issues 2-3: 252-261

WANG Q.S., LUO J., CAI L.M., MU G.Z., WANG H.Z., JIANG H.H., WANG S., HE M.H. 2018.Distribution of soil selenium and its influential factors in Jiexi County, Guangdong Province. Soils, 50 [6]:1126-1133

WHANGER P.D. 2004. Selenium and its relationship to cancer: an update. British Journal of Nutrition, 91: 1128. doi: 10.1079/BJN20031015.

YANG C, YAO H, WU Y. SUN G., YANG W., LI Z., SHANG L. 2021. Status and risks of selenium deficiency in a traditional selenium-deficient area in Northeast China. Science of The Total Environment, 762: 144103. doi.org/10.1016/j. scitotenv.2020.144103.

ZAGRODZKI P. 2000. Selen w żywieniu człowieka. Cz.l. Zawartość selenu w żywności, zalecane i rzeczywiste spożycie selenu. Bromatologia i Chemia Toksykologiczna, 3:209-214.

ZHU J.M., WANG N., LI S.H., LI L., SU H.C., LIU C.X. 2008. Distribution and transport of selenium in Yutangba, China: Impact of human activities. Science of The Total Environment

ŻARCZYŃSKA K., SOBIECH P., RADWIŃSKA J., RĘKAWEK W. 2013. Effects of selenium on animal health. Journal of Elementology, 18[2]: 329-340. 